\title{
Kinetics of Hydrogen Bonding between Ions of Opposite and Ions of Like Charge in Hydroxy-Functionalized Ionic Liquids
}

\author{
Jan Neumann ${ }^{\dagger}$, Dietmar Paschek ${ }^{\dagger}$, Anne Strate ${ }^{\dagger, \ddagger}$, Ralf Ludwig $^{\dagger, \ddagger}, \boldsymbol{\Phi}$ \\ $\dagger$ Institut für Chemie, Abteilung Physikalische und Theoretische Chemie, \\ Universität Rostock, Dr.-Lorenz-Weg 2, D-18059 Rostock, Germany \\ $\ddagger$ Department Life, Light \& Matter, Universität Rostock, \\ Albert-Einstein-Straße 25, D-18059 Rostock, Germany \\ ฯ Leibniz Institut für Katalyse an der Universität Rostock, \\ Albert-Einstein-Straße 29a, D-18059 Rostock, Germany
}

E-mail: ralf.ludwig@uni-rostock.de

\section{Forcefields}

The force-field of the $\left[\mathrm{NTf}_{2}\right]^{-}$anion has been published in reference [1]. The force fields for the pyridinium cations were derived from the OPLS firce field for pyridine from Jorgensen et al.[2, 3] The point charges were derived from the electrostatic potential around the all-trans conformation of the respective cation according to the CHelpG scheme.[4] The dihedral potential of the hydroxyalkyl chains were calculated employing second order Møller-Plesset perturbation theory using the cc-pvtz basis set using Gaussian 09.[5] Energy profiles $V_{\kappa \lambda \omega \tau}^{\mathrm{QM}}(\psi)$ of a given dihedral between the atoms $\kappa, \lambda, \omega$ and $\tau$ were obtained by rotating each dihedral individually in steps of $10^{\circ}$ to a total of $360^{\circ}$ starting from the all-trans conformation. The non-bonded interaction energy of every conformation $V_{\kappa \lambda \omega \tau}^{\mathrm{nb}}(\psi)$ was calculated following the same procedure using MOSCITO.[6] The dihedral potential for a given dihedral was then calculated as $V_{\kappa \lambda \omega \tau}^{\mathrm{dp}}(\psi)=V_{\kappa \lambda \omega \tau}^{\mathrm{QM}}(\psi)-V_{\kappa \lambda \omega \tau}^{\mathrm{nb}}(\psi)$ and fitted to

$$
V_{\kappa \lambda \omega \tau}^{\mathrm{dp}}(\psi)=\sum_{n} k_{m}^{\mathrm{dp}}\left[1+\cos \left(m_{n} \psi_{m}-\psi_{m}^{0}\right)\right] .
$$


Table S1: Lennard-Jones parameters $\sigma$ and $\epsilon$ for all interaction sites of the $\left[\mathrm{HOC}_{2} \mathrm{Py}\right]^{+}$, $\left[\mathrm{HOC}_{3} \mathrm{Py}\right]^{+},\left[\mathrm{HOC}_{4} \mathrm{Py}\right]^{+}$and $\left[\mathrm{HOC}_{5} \mathrm{Py}\right]^{+}$cation.

\begin{tabular}{crc}
\hline site & $\sigma / \AA$ & $\epsilon \cdot k_{\mathrm{B}}^{-1} / \mathrm{K}$ \\
\hline $\mathrm{N}$ & 3.25 & 85.55 \\
$\mathrm{C}_{\mathrm{a}}$ & 3.55 & 35.23 \\
$\mathrm{H}_{\mathrm{a}}$ & 2.42 & 15.10 \\
$\mathrm{C}_{\mathrm{c}}$ & 3.50 & 33.20 \\
$\mathrm{C}_{\mathrm{m}}$ & 3.50 & 33.20 \\
$\mathrm{H}_{\mathrm{c}}$ & 2.50 & 15.10 \\
$\mathrm{O}$ & 3.12 & 85.60 \\
$\mathrm{H}_{\mathrm{o}}$ & 0.00 & 0.00 \\
\hline
\end{tabular}

Table S2: Bond length $r_{\kappa \lambda}^{0}$ and angle parameters $\phi_{\kappa \lambda \omega}^{0}$ und $k_{\kappa \lambda \omega}^{\mathrm{a}}$ for the angle potential $V_{\kappa \lambda \omega}^{\mathrm{a}}=\frac{1}{2} k_{\kappa \lambda \omega}^{\mathrm{a}}\left(\phi_{\kappa \lambda \omega}-\phi_{\kappa \lambda \omega}^{0}\right)^{2}$ in the force field of the $\left[\mathrm{HOC}_{2} \mathrm{Py}\right]^{+},\left[\mathrm{HOC}_{3} \mathrm{Py}\right]^{+},\left[\mathrm{HOC}_{4} \mathrm{Py}\right]^{+}$ and $\left[\mathrm{HOC}_{5} \mathrm{Py}\right]^{+}$cation.

\begin{tabular}{cc|ccc}
\hline bond & $r_{\kappa \lambda}^{0} / \AA$ & angle & $\phi_{\kappa \lambda \omega}^{0} /{ }^{\circ}$ & $k_{\kappa \lambda \omega}^{\mathrm{a}} / \mathrm{kJ} \mathrm{mol}^{-1} \mathrm{rad}^{-2}$ \\
\hline $\mathrm{C}_{\mathrm{a}}-\mathrm{N}$ & 1.339 & $\mathrm{C}_{\mathrm{a}}-\mathrm{C}_{\mathrm{a}}-\mathrm{C}_{\mathrm{a}}$ & 120.0 & 527.20 \\
$\mathrm{C}_{\mathrm{a}}-\mathrm{H}_{\mathrm{a}}$ & 1.080 & $\mathrm{C}_{\mathrm{a}}-\mathrm{C}_{\mathrm{a}}-\mathrm{N}$ & 124.0 & 585.80 \\
$\mathrm{C}_{\mathrm{a}}-\mathrm{C}_{\mathrm{a}}$ & 1.400 & $\mathrm{C}_{\mathrm{a}}-\mathrm{N}-\mathrm{C}_{\mathrm{a}}$ & 117.0 & 585.80 \\
$\mathrm{~N}^{-} \mathrm{C}_{\mathrm{c}}$ & 1.339 & $\mathrm{C}_{\mathrm{a}}-\mathrm{C}_{\mathrm{a}}-\mathrm{H}_{\mathrm{a}}$ & 120.0 & 292.90 \\
$\mathrm{C}_{\mathrm{c}}-\mathrm{C}_{\mathrm{c}}$ & 1.529 & $\mathrm{~N}-\mathrm{C}_{\mathrm{a}}-\mathrm{H}_{\mathrm{a}}$ & 116.0 & 292.90 \\
$\mathrm{C}_{\mathrm{c}}-\mathrm{H}_{\mathrm{c}}$ & 1.090 & $\mathrm{C}_{\mathrm{a}}-\mathrm{N}-\mathrm{C}_{\mathrm{c}}$ & 121.5 & 585.80 \\
$\mathrm{C}_{\mathrm{c}}-\mathrm{O}$ & 1.410 & $\mathrm{~N}-\mathrm{C}_{\mathrm{c}}-\mathrm{C}_{\mathrm{c}}$ & 112.7 & 487.43 \\
$\mathrm{O}-\mathrm{H}_{\mathrm{o}}$ & 0.945 & $\mathrm{H}_{\mathrm{c}}-\mathrm{C}_{\mathrm{c}}-\mathrm{N}$ & 110.7 & 313.26 \\
$\mathrm{C}_{\mathrm{c}}-\mathrm{C}_{\mathrm{m}}$ & 1.529 & $\mathrm{H}_{\mathrm{c}}-\mathrm{C}_{\mathrm{c}}-\mathrm{H}_{\mathrm{c}}$ & 107.8 & 275.70 \\
& & $\mathrm{H}_{\mathrm{c}}-\mathrm{C}_{\mathrm{c}}-\mathrm{C}_{\mathrm{c}}$ & 110.7 & 313.26 \\
& $\mathrm{C}_{\mathrm{c}}-\mathrm{C}_{\mathrm{c}}-\mathrm{C}_{\mathrm{c}}$ & 112.7 & 487.43 \\
& & $\mathrm{C}_{\mathrm{c}}-\mathrm{C}_{\mathrm{c}}-\mathrm{C}_{\mathrm{m}}$ & 112.7 & 487.43 \\
& & $\mathrm{H}_{\mathrm{c}}-\mathrm{C}_{\mathrm{c}}-\mathrm{C}_{\mathrm{m}}$ & 110.7 & 313.26 \\
& $\mathrm{H}_{\mathrm{c}}-\mathrm{C}_{\mathrm{m}}-\mathrm{C}_{\mathrm{c}}$ & 110.7 & 313.26 \\
& & $\mathrm{H}_{\mathrm{c}}-\mathrm{C}_{\mathrm{m}}-\mathrm{H}_{\mathrm{c}}$ & 107.8 & 275.70 \\
& & $\mathrm{H}_{\mathrm{o}}-\mathrm{O}_{-}-\mathrm{C}_{\mathrm{m}}$ & 108.5 & 460.55 \\
& & $\mathrm{C}_{\mathrm{c}}-\mathrm{C}_{\mathrm{m}}-\mathrm{O}$ & 109.5 & 418.68 \\
& & $\mathrm{H}_{\mathrm{c}}-\mathrm{C}_{\mathrm{m}}-\mathrm{O}$ & 109.5 & 293.08 \\
\hline
\end{tabular}


Table S3: Parameters $m_{n}, k_{m}^{\mathrm{dp}}$ and $\psi_{m}^{0}$ for the improper dihedral potential $V_{\kappa \lambda \omega \tau}^{\mathrm{dp}}=$ $\sum_{n} k_{m}^{\mathrm{dp}}\left[1+\cos \left(m_{n} \psi_{m}-\psi_{m}^{0}\right)\right]$ in the force field of the $\left[\mathrm{HOC}_{2} \mathrm{Py}\right]^{+}, \quad\left[\mathrm{HOC}_{3} \mathrm{Py}\right]^{+}$, $\left[\mathrm{HOC}_{4} \mathrm{Py}\right]^{+}$and $\left[\mathrm{HOC}_{5} \mathrm{Py}\right]^{+}$cation. The central atom is the first in the list.

\begin{tabular}{cccc}
\hline & $m_{n}$ & $k_{m}^{\mathrm{dp}} / \mathrm{kJ} \mathrm{mol}^{-1}$ & $\psi_{m}^{0} /{ }^{\circ}$ \\
\hline $\mathrm{N}-\mathrm{C}_{\mathrm{a}}-\mathrm{C}_{\mathrm{a}}-\mathrm{C}_{\mathrm{c}}$ & 2 & 4.6060 & 180.0 \\
\hline $\mathrm{C}_{\mathrm{a}}-\mathrm{N}-\mathrm{C}_{\mathrm{a}}-\mathrm{H}_{\mathrm{a}}$ & 2 & 4.6060 & 180.0 \\
\hline $\mathrm{C}_{\mathrm{a}}-\mathrm{C}_{\mathrm{a}}-\mathrm{C}_{\mathrm{a}}-\mathrm{H}_{\mathrm{a}}$ & 2 & 4.6060 & 180.0 \\
\hline
\end{tabular}

Table S4: Parameters $m_{n}, k_{m}^{\mathrm{dp}}$ and $\psi_{m}^{0}$ for the torsion potential $V_{\kappa \lambda \omega \tau}^{\mathrm{dp}}=\sum_{n} k_{m}^{\mathrm{dp}}[1+$ $\left.\cos \left(m_{n} \psi_{m}-\psi_{m}^{0}\right)\right]$ in the force field of the $\left[\mathrm{HOC}_{2} \mathrm{Py}\right]^{+}$cation.

\begin{tabular}{ccccc}
\hline & $n(\kappa \lambda \omega \tau)$ & $m_{n}$ & $k_{m}^{\mathrm{dp}} / \mathrm{kJ} \mathrm{mol}^{-1}$ & $\psi_{m}^{0} /{ }^{\circ}$ \\
\hline $\mathrm{X}-\mathrm{C}_{\mathrm{a}}-\mathrm{C}_{\mathrm{a}}-\mathrm{X}$ & 1 & 2 & 15.1780 & 180.0 \\
\hline $\mathrm{X}-\mathrm{C}_{\mathrm{a}}-\mathrm{N}-\mathrm{X}$ & 1 & 2 & 15.1780 & 180.0 \\
\hline $\mathrm{C}_{\mathrm{a}}-\mathrm{N}-\mathrm{C}_{\mathrm{c}}-\mathrm{C}_{\mathrm{c}}$ & 1 & 2 & 0.0802 & 0 \\
& 2 & 4 & -0.4693 & 0 \\
\hline $\mathrm{N}-\mathrm{C}_{\mathrm{c}}-\mathrm{C}_{\mathrm{c}}-\mathrm{O}$ & 1 & 1 & -0.7375 & 0.0 \\
& 2 & 2 & 1.8576 & 0.0 \\
& 3 & 3 & 7.2898 & 0.0 \\
\hline $\mathrm{C}_{\mathrm{c}}-\mathrm{C}_{\mathrm{c}}-\mathrm{O}-\mathrm{H}_{\mathrm{o}}$ & 1 & 1 & -5.8097 & 0.0 \\
& 2 & 2 & 1.8939 & 0.0 \\
& 3 & 3 & 2.5150 & 0.0
\end{tabular}




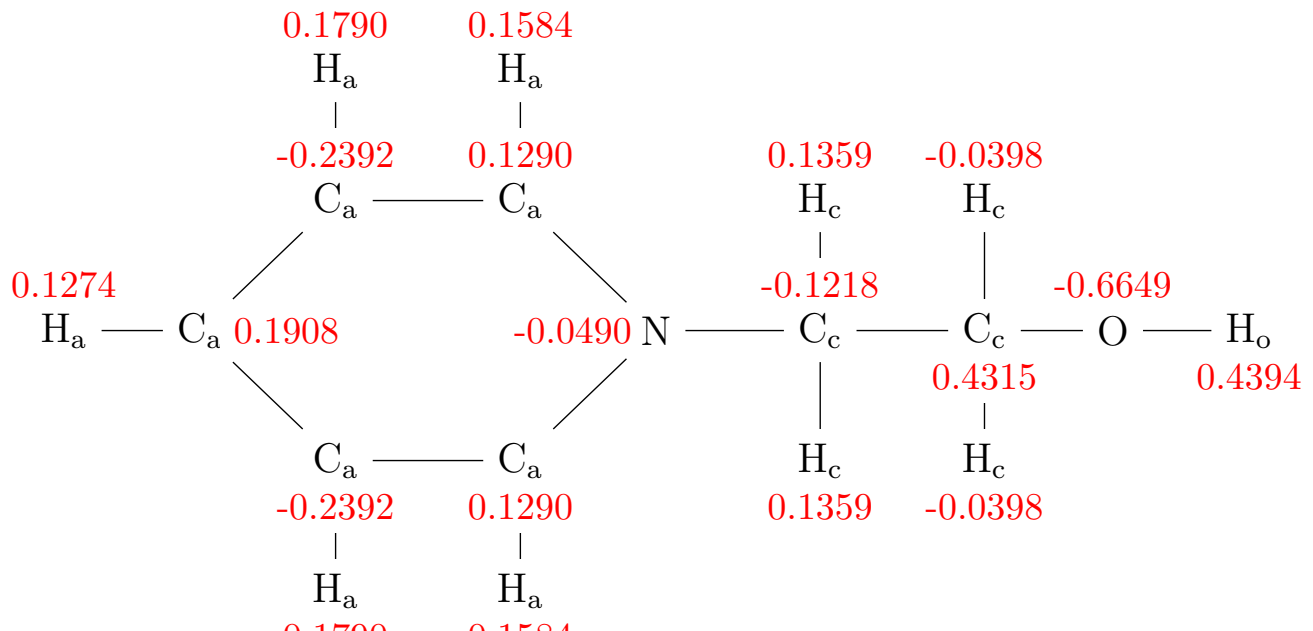

Figure S1: Structure of the $\left[\mathrm{HOC}_{2} \mathrm{Py}\right]^{+}$cation with atom types and corresponding point charges $q$ /e in red.

Table S5: Parameters $m_{n}, k_{m}^{\mathrm{dp}}$ and $\psi_{m}^{0}$ for the torsion potential $V_{\kappa \lambda \omega \tau}^{\mathrm{dp}}=\sum_{n} k_{m}^{\mathrm{dp}}[1+$ $\left.\cos \left(m_{n} \psi_{m}-\psi_{m}^{0}\right)\right]$ in the force field of the $\left[\mathrm{HOC}_{3} \mathrm{Py}\right]^{+}$cation.

\begin{tabular}{ccccc}
\hline & $n(\kappa \lambda \omega \tau)$ & $m_{n}$ & $k_{m}^{\mathrm{dp}} / \mathrm{kJ} \mathrm{mol}^{-1}$ & $\psi_{m}^{0} /{ }^{\circ}$ \\
\hline $\mathrm{X}-\mathrm{C}_{\mathrm{a}}-\mathrm{C}_{\mathrm{a}}-\mathrm{X}$ & 1 & 2 & 15.1780 & 180.0 \\
\hline $\mathrm{X}-\mathrm{C}_{\mathrm{a}}-\mathrm{N}-\mathrm{X}$ & 1 & 2 & 15.1780 & 180.0 \\
\hline $\mathrm{C}_{\mathrm{a}}-\mathrm{N}-\mathrm{C}_{\mathrm{c}}-\mathrm{C}_{\mathrm{c}}$ & 1 & 2 & -0.7379 & 0 \\
& 2 & 4 & -0.2237 & 0 \\
\hline $\mathrm{N}-\mathrm{C}_{\mathrm{c}}-\mathrm{C}_{\mathrm{c}}-\mathrm{C}_{\mathrm{c}}$ & 1 & 1 & -3.0206 & 0.0 \\
& 2 & 2 & 0.6685 & 0.0 \\
& 3 & 3 & 5.1206 & 0.0 \\
& 4 & 4 & 0.4708 & 0.0 \\
\hline $\mathrm{C}_{\mathrm{c}}-\mathrm{C}_{\mathrm{c}}-\mathrm{C}_{\mathrm{c}}-\mathrm{O}$ & 1 & 1 & 4.1980 & 0.0 \\
& 2 & 3 & 5.2448 & 0.0 \\
& 3 & 4 & 1.0859 & 0.0 \\
\hline $\mathrm{C}_{\mathrm{c}}-\mathrm{C}_{\mathrm{c}}-\mathrm{O}-\mathrm{H}_{\mathrm{o}}$ & 1 & 1 & -1.8926 & 0.0 \\
& 2 & 2 & 1.0349 & 0.0 \\
& 3 & 3 & 2.5840 & 0.0 \\
& 4 & 4 & 0.0316 & 0.0 \\
\hline
\end{tabular}




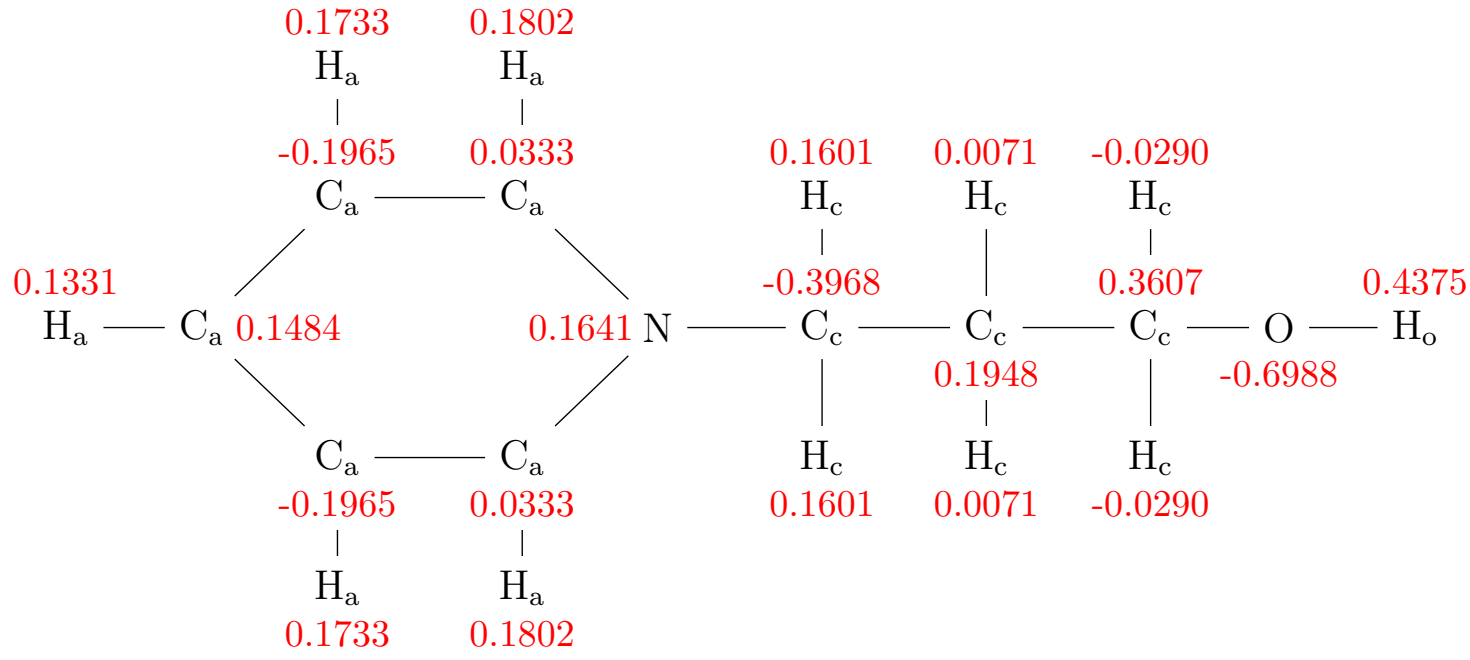

Figure S2: Structure of the $\left[\mathrm{HOC}_{3} \mathrm{Py}\right]^{+}$cation with atom types and corresponding point charges $q$ /e in red.

Table S6: Parameters $m_{n}, k_{m}^{\mathrm{dp}}$ and $\psi_{m}^{0}$ for the torsion potential $V_{\kappa \lambda \omega \tau}^{\mathrm{dp}}=\sum_{n} k_{m}^{\mathrm{dp}}[1+$ $\left.\cos \left(m_{n} \psi_{m}-\psi_{m}^{0}\right)\right]$ in the force field of the $\left[\mathrm{HOC}_{4} \mathrm{Py}\right]^{+}$cation.

\begin{tabular}{ccccc}
\hline & $n(\kappa \lambda \omega \tau)$ & $m_{n}$ & $k_{m}^{\mathrm{dp}} / \mathrm{kJ} \mathrm{mol}^{-1}$ & $\psi_{m}^{0} /{ }^{\circ}$ \\
\hline $\mathrm{X}-\mathrm{C}_{\mathrm{a}}-\mathrm{C}_{\mathrm{a}}-\mathrm{X}$ & 1 & 2 & 15.1780 & 180.0 \\
\hline $\mathrm{X}-\mathrm{C}_{\mathrm{a}}-\mathrm{N}-\mathrm{X}$ & 1 & 2 & 15.1780 & 180.0 \\
\hline $\mathrm{C}_{\mathrm{a}}-\mathrm{N}-\mathrm{C}_{\mathrm{c}}-\mathrm{C}_{\mathrm{c}}$ & 1 & 2 & -0.3579 & 0 \\
$\mathrm{C}_{\mathrm{a}}-\mathrm{N}-\mathrm{C}_{\mathrm{c}}-\mathrm{C}_{\mathrm{c}}$ & 2 & 4 & -0.4037 & 0 \\
\hline $\mathrm{C}_{\mathrm{c}}-\mathrm{C}_{\mathrm{c}}-\mathrm{C}_{\mathrm{c}}-\mathrm{C}_{\mathrm{c}}$ & 1 & 1 & -0.2825 & 0.0 \\
& 2 & 2 & 0.6065 & 0.0 \\
& 3 & 3 & 4.6858 & 0.0 \\
& 4 & 4 & 0.7018 & 0.0 \\
& 5 & 5 & 0.4468 & 0.0 \\
& 6 & 6 & 0.4564 & 0.0 \\
\hline $\mathrm{C}_{\mathrm{c}}-\mathrm{C}_{\mathrm{c}}-\mathrm{C}_{\mathrm{c}}-\mathrm{O}$ & 1 & 1 & -2.3748 & 0.0 \\
& 2 & 3 & 6.8089 & 0.0 \\
& 3 & 4 & 0.9531 & 0.0 \\
\hline $\mathrm{C}_{\mathrm{c}}-\mathrm{C}_{\mathrm{c}}-\mathrm{O}-\mathrm{H}_{\mathrm{o}}$ & 1 & 1 & -3.5552 & 0.0 \\
& 2 & 2 & 0.5886 & 0.0 \\
& 3 & 3 & 2.5272 & 0.0 \\
& 4 & 4 & 0.1504 & 0.0
\end{tabular}




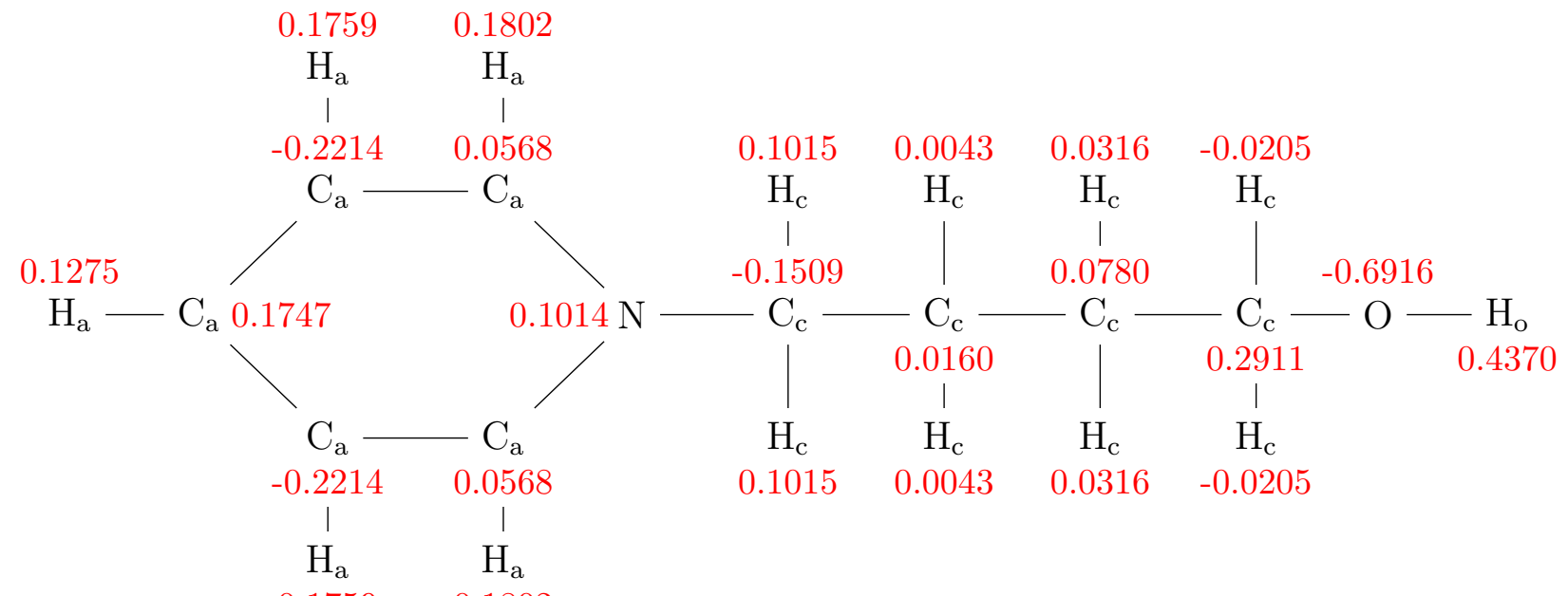

$0.1759 \quad 0.1802$

Figure S3: Structure of the $\left[\mathrm{HOC}_{4} \mathrm{Py}\right]^{+}$cation with atom types and corresponding point charges in red. 
Table S7: Parameters $m_{n}, k_{m}^{\mathrm{dp}}$ and $\psi_{m}^{0}$ for the torsion potential $V_{\kappa \lambda \omega \tau}^{\mathrm{dp}}=\sum_{n} k_{m}^{\mathrm{dp}}[1+$ $\left.\cos \left(m_{n} \psi_{m}-\psi_{m}^{0}\right)\right]$ in the force field of the $\left[\mathrm{HOC}_{5} \mathrm{Py}\right]^{+}$cation.

\begin{tabular}{|c|c|c|c|c|}
\hline & $n(\kappa \lambda \omega \tau)$ & $m_{n}$ & $k_{m}^{\mathrm{dp}} / \mathrm{kJ} \mathrm{mol}^{-1}$ & $\psi_{m}^{0} /^{\circ}$ \\
\hline $\mathrm{X}-\mathrm{C}_{\mathrm{a}}-\mathrm{C}_{\mathrm{a}}-\mathrm{X}$ & 1 & 2 & 15.1780 & 180.0 \\
\hline $\mathrm{X}-\mathrm{C}_{\mathrm{a}}-\mathrm{N}-\mathrm{X}$ & 1 & 2 & 15.1780 & 180.0 \\
\hline $\mathrm{C}_{\mathrm{a}}-\mathrm{N}-\mathrm{C}_{\mathrm{c}}-\mathrm{C}_{\mathrm{c}}$ & 1 & 2 & -0.4663 & 0 \\
\hline $\mathrm{C}_{\mathrm{a}}-\mathrm{N}-\mathrm{C}_{\mathrm{c}}-\mathrm{C}_{\mathrm{c}}$ & 2 & 4 & -0.3648 & 0 \\
\hline \multirow[t]{6}{*}{$\mathrm{C}_{\mathrm{c}}-\mathrm{C}_{\mathrm{c}}-\mathrm{C}_{\mathrm{c}}-\mathrm{C}_{\mathrm{c}}$} & 1 & 1 & -0.9736 & 0.0 \\
\hline & 2 & 2 & 0.1905 & 0.0 \\
\hline & 3 & 3 & 5.6022 & 0.0 \\
\hline & 4 & 4 & 0.6932 & 0.0 \\
\hline & 5 & 5 & 0.3076 & 0.0 \\
\hline & 6 & 6 & 0.3493 & 0.0 \\
\hline \multirow[t]{6}{*}{$\mathrm{C}_{\mathrm{c}}-\mathrm{C}_{\mathrm{c}}-\mathrm{C}_{\mathrm{c}}-\mathrm{C}_{\mathrm{m}}$} & 1 & 1 & 2.2559 & 0.0 \\
\hline & 2 & 2 & 0.5340 & 0.0 \\
\hline & 3 & 3 & 4.9032 & 0.0 \\
\hline & 4 & 4 & 0.6508 & 0.0 \\
\hline & 5 & 5 & 0.3897 & 0.0 \\
\hline & 6 & 6 & 0.4302 & 0.0 \\
\hline \multirow[t]{4}{*}{$\mathrm{C}_{\mathrm{c}}-\mathrm{C}_{\mathrm{c}}-\mathrm{C}_{\mathrm{m}}-\mathrm{O}$} & 1 & 1 & 0.2341 & 0.0 \\
\hline & 2 & 2 & 0.4898 & 0.0 \\
\hline & 3 & 3 & 6.6545 & 0.0 \\
\hline & 4 & 4 & 0.9830 & 0.0 \\
\hline \multirow[t]{4}{*}{$\mathrm{C}_{\mathrm{c}}-\mathrm{C}_{\mathrm{c}}-\mathrm{O}-\mathrm{H}_{\mathrm{o}}$} & 1 & 1 & -3.4972 & 0.0 \\
\hline & 2 & 2 & 0.3471 & 0.0 \\
\hline & 3 & 3 & 2.5003 & 0.0 \\
\hline & 4 & 4 & 0.0941 & 0.0 \\
\hline
\end{tabular}




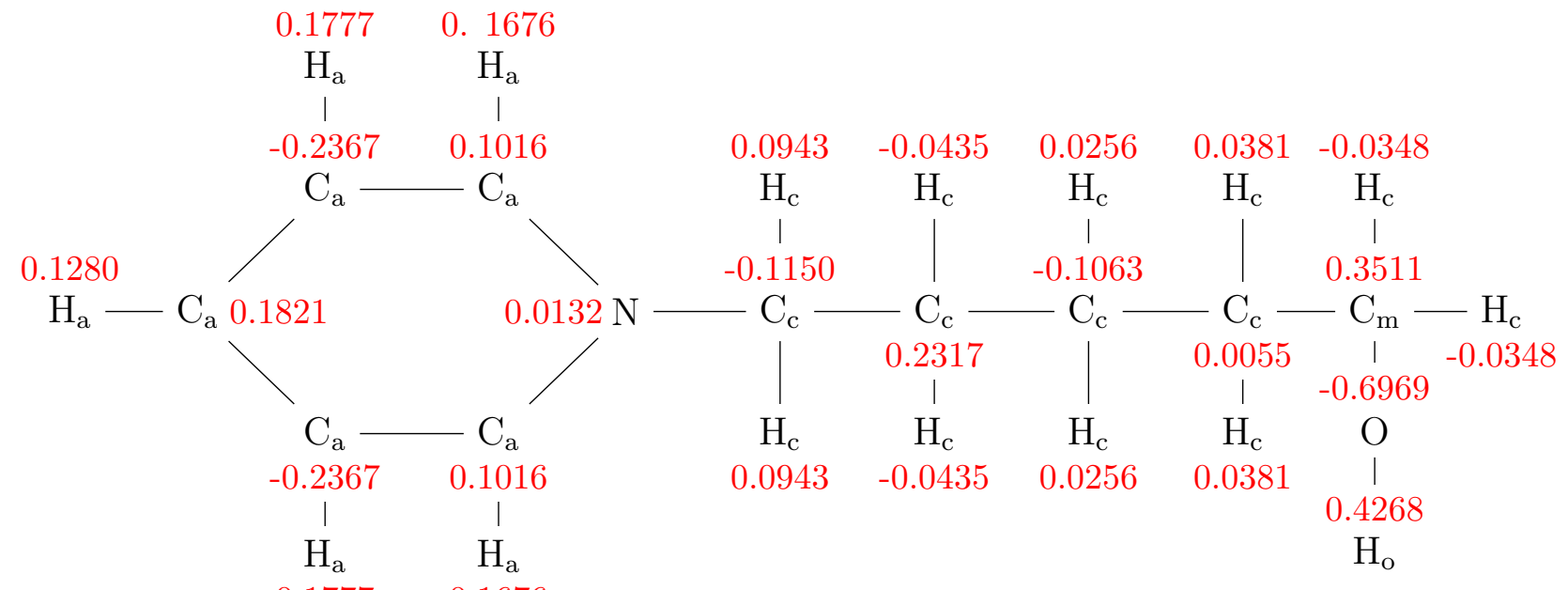

$0.1777 \quad 0.1676$

Figure S4: Structure of the $\left[\mathrm{HOC}_{5} \mathrm{Py}\right]^{+}$cation with atom types and corresponding point charges in red.

Table S8: Parameters $m_{n}, k_{m}^{\mathrm{dp}}$ and $\psi_{m}^{0}$ for the torsion potential $V_{\kappa \lambda \omega \tau}^{\mathrm{dp}}=\sum_{n} k_{m}^{\mathrm{dp}}[1+$ $\left.\cos \left(m_{n} \psi_{m}-\psi_{m}^{0}\right)\right]$ in the force field of the $\left[\mathrm{C}_{3} \mathrm{Py}\right]^{+}$cation.

\begin{tabular}{ccccc}
\hline & $n(\kappa \lambda \omega \tau)$ & $m_{n}$ & $k_{m}^{\mathrm{dp}} / \mathrm{kJ} \mathrm{mol}^{-1}$ & $\psi_{m}^{0} /{ }^{\circ}$ \\
\hline $\mathrm{X}-\mathrm{C}_{\mathrm{a}}-\mathrm{C}_{\mathrm{a}}-\mathrm{X}$ & 1 & 2 & 15.1780 & 180.0 \\
\hline $\mathrm{X}-\mathrm{C}_{\mathrm{a}}-\mathrm{N}-\mathrm{X}$ & 1 & 2 & 15.1780 & 180.0 \\
\hline $\mathrm{C}_{\mathrm{a}}-\mathrm{N}-\mathrm{C}_{\mathrm{c}}-\mathrm{C}_{\mathrm{c}}$ & 1 & 2 & -0.4178 & 0 \\
& 2 & 4 & -0.4138 & 0 \\
\hline $\mathrm{N}-\mathrm{C}_{\mathrm{c}}-\mathrm{C}_{\mathrm{c}}-\mathrm{C}_{\mathrm{m}}$ & 1 & 1 & -1.4934 & 0.0 \\
& 2 & 3 & 6.8503 & 0.0 \\
\hline $\mathrm{C}_{\mathrm{c}}-\mathrm{C}_{\mathrm{c}}-\mathrm{C}_{\mathrm{m}}-\mathrm{H}_{\mathrm{m}}$ & 1 & 3 & 1.8318 & 0.0 \\
\hline
\end{tabular}




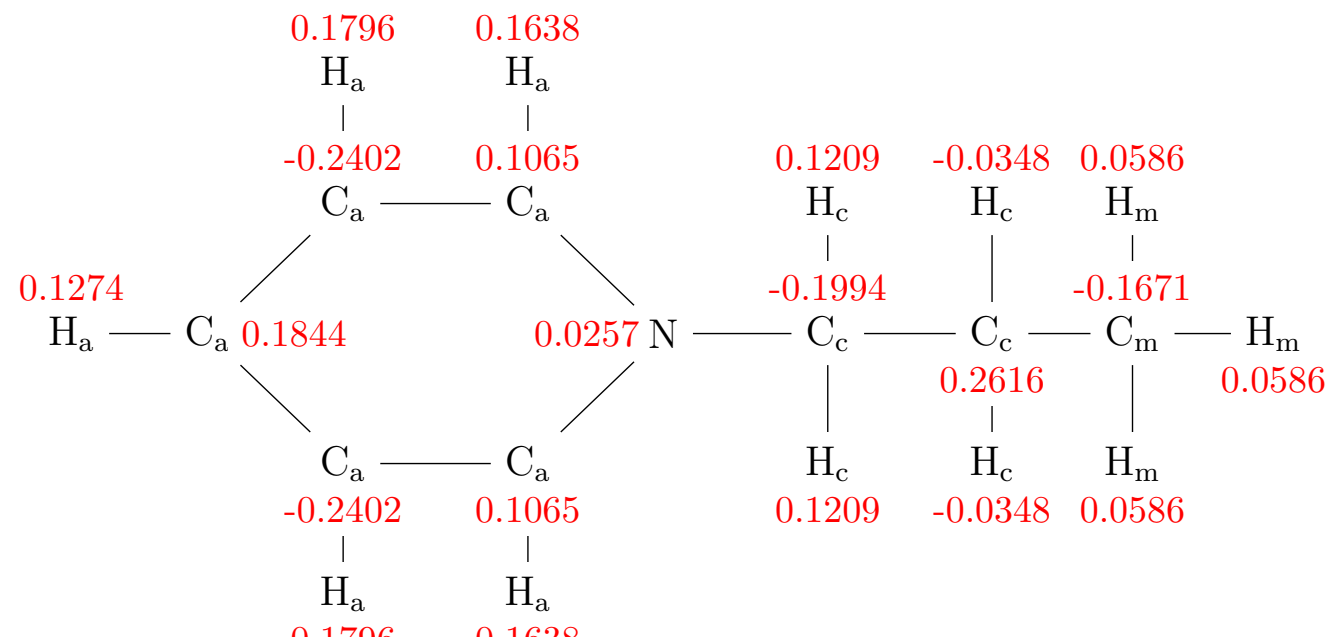

Figure S5: Structure of the $\left[\mathrm{C}_{3} \mathrm{Py}\right]^{+}$cation with atom types and corresponding point charges $q /$ e in red.

Table S9: Parameters $m_{n}, k_{m}^{\mathrm{dp}}$ and $\psi_{m}^{0}$ for the torsion potential $V_{\kappa \lambda \omega \tau}^{\mathrm{dp}}=\sum_{n} k_{m}^{\mathrm{dp}}[1+$ $\left.\cos \left(m_{n} \psi_{m}-\psi_{m}^{0}\right)\right]$ in the force field of the $\left[\mathrm{C}_{4} \mathrm{Py}\right]^{+}$cation.

\begin{tabular}{ccccc}
\hline & $n(\kappa \lambda \omega \tau)$ & $m_{n}$ & $k_{m}^{\mathrm{dp}} / \mathrm{kJ} \mathrm{mol}^{-1}$ & $\psi_{m}^{0} /{ }^{\circ}$ \\
\hline $\mathrm{X}-\mathrm{C}_{\mathrm{a}}-\mathrm{C}_{\mathrm{a}}-\mathrm{X}$ & 1 & 2 & 15.1780 & 180.0 \\
\hline $\mathrm{X}-\mathrm{C}_{\mathrm{a}}-\mathrm{N}-\mathrm{X}$ & 1 & 2 & 15.1780 & 180.0 \\
\hline $\mathrm{C}_{\mathrm{a}}-\mathrm{N}-\mathrm{C}_{\mathrm{c}}-\mathrm{C}_{\mathrm{c}}$ & 1 & 2 & -0.4052 & 0 \\
& 2 & 4 & -0.4532 & 0 \\
\hline $\mathrm{N}-\mathrm{C}_{\mathrm{c}}-\mathrm{C}_{\mathrm{c}}-\mathrm{C}_{\mathrm{c}}$ & 1 & 1 & -2.9345 & 0.0 \\
& 2 & 3 & 6.6723 & 0.0 \\
& 3 & 4 & 0.3431 & 0.0 \\
\hline $\mathrm{C}_{\mathrm{c}}-\mathrm{C}_{\mathrm{c}}-\mathrm{C}_{\mathrm{c}}-\mathrm{C}_{\mathrm{m}}$ & 1 & 1 & 2.4114 & 0.0 \\
& 2 & 2 & 0.3899 & 0.0 \\
& 3 & 3 & 5.6540 & 0.0 \\
& 4 & 4 & 0.5565 & 0.0 \\
& 5 & 5 & 0.3099 & 0.0 \\
\hline $\mathrm{C}_{\mathrm{c}}-\mathrm{C}_{\mathrm{c}}-\mathrm{C}_{\mathrm{m}}-\mathrm{H}_{\mathrm{m}}$ & 1 & 3 & 1.8976 & 0.0 \\
\hline
\end{tabular}




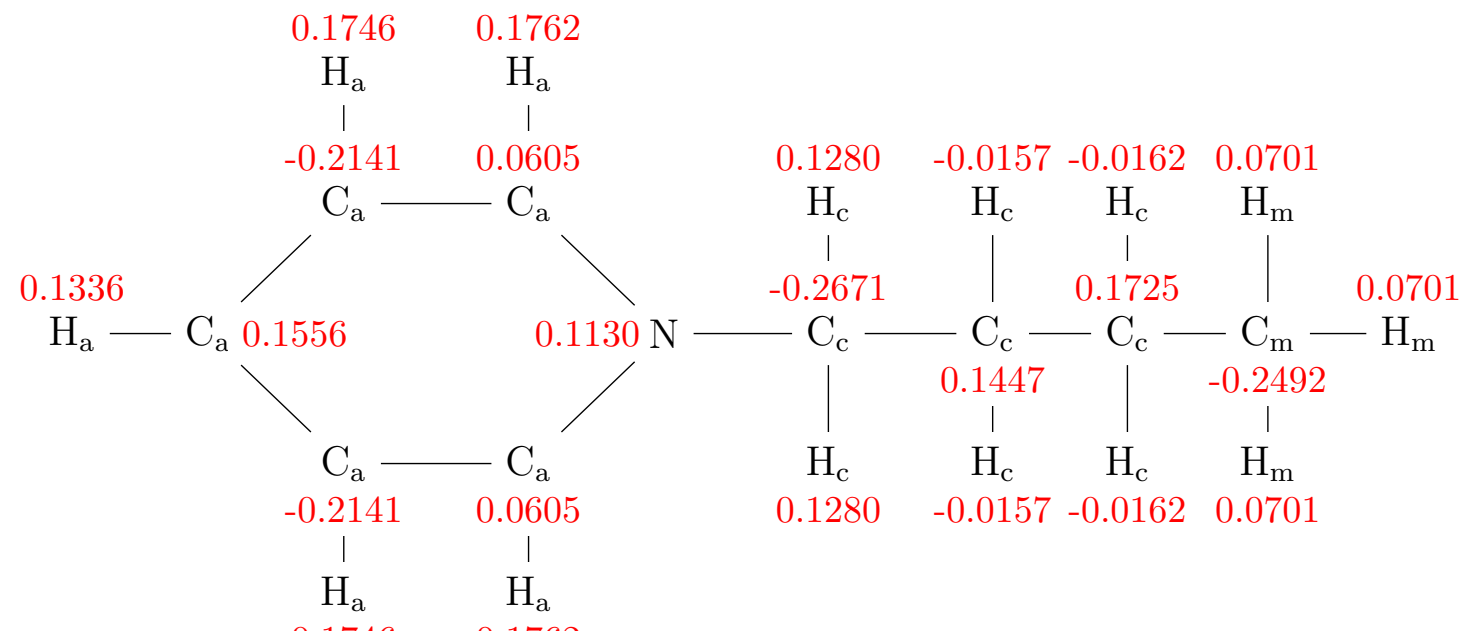

Figure S6: Structure of the $\left[\mathrm{C}_{4} \mathrm{Py}\right]^{+}$cation with atom types and corresponding point charges $q$ /e in red.

Table S10: Parameters $m_{n}, k_{m}^{\mathrm{dp}}$ and $\psi_{m}^{0}$ for the torsion potential $V_{\kappa \lambda \omega \tau}^{\mathrm{dp}}=\sum_{n} k_{m}^{\mathrm{dp}}[1+$ $\left.\cos \left(m_{n} \psi_{m}-\psi_{m}^{0}\right)\right]$ in the force field of the $\left[\mathrm{C}_{5} \mathrm{Py}\right]^{+}$cation.

\begin{tabular}{ccccc}
\hline & $n(\kappa \lambda \omega \tau)$ & $m_{n}$ & $k_{m}^{\mathrm{dp}} / \mathrm{kJ} \mathrm{mol}^{-1}$ & $\psi_{m}^{0} /{ }^{\circ}$ \\
\hline $\mathrm{X}-\mathrm{C}_{\mathrm{a}}-\mathrm{C}_{\mathrm{a}}-\mathrm{X}$ & 1 & 2 & 15.1780 & 180.0 \\
\hline $\mathrm{X}-\mathrm{C}_{\mathrm{a}}-\mathrm{N}-\mathrm{X}$ & 1 & 2 & 15.1780 & 180.0 \\
\hline $\mathrm{C}_{\mathrm{a}}-\mathrm{N}-\mathrm{C}_{\mathrm{c}}-\mathrm{C}_{\mathrm{c}}$ & 1 & 2 & -0.4172 & 0 \\
& 2 & 4 & -0.4759 & 0 \\
\hline $\mathrm{N}-\mathrm{C}_{\mathrm{c}}-\mathrm{C}_{\mathrm{c}}-\mathrm{C}_{\mathrm{c}}$ & 1 & 1 & -2.9885 & 0.0 \\
& 2 & 3 & 6.7221 & 0.0 \\
& 3 & 4 & 0.3547 & 0.0 \\
\hline $\mathrm{C}_{\mathrm{c}}-\mathrm{C}_{\mathrm{c}}-\mathrm{C}_{\mathrm{c}}-\mathrm{C}_{\mathrm{c}}$ & 1 & 1 & -0.4882 & 0.0 \\
& 2 & 2 & 0.2620 & 0.0 \\
& 3 & 3 & 5.3908 & 0.0 \\
& 4 & 4 & 0.6635 & 0.0 \\
& 5 & 5 & 0.3339 & 0.0 \\
\hline $\mathrm{C}_{\mathrm{c}}-\mathrm{C}_{\mathrm{c}}-\mathrm{C}_{\mathrm{c}}-\mathrm{C}_{\mathrm{m}}$ & 1 & 3 & 6.0396 & 0.0 \\
& 2 & 4 & 0.5463 & 0.0 \\
\hline $\mathrm{C}_{\mathrm{c}}-\mathrm{C}_{\mathrm{c}}-\mathrm{C}_{\mathrm{m}}-\mathrm{H}_{\mathrm{m}}$ & 1 & 3 & 1.8773 & 0.0 \\
\hline
\end{tabular}




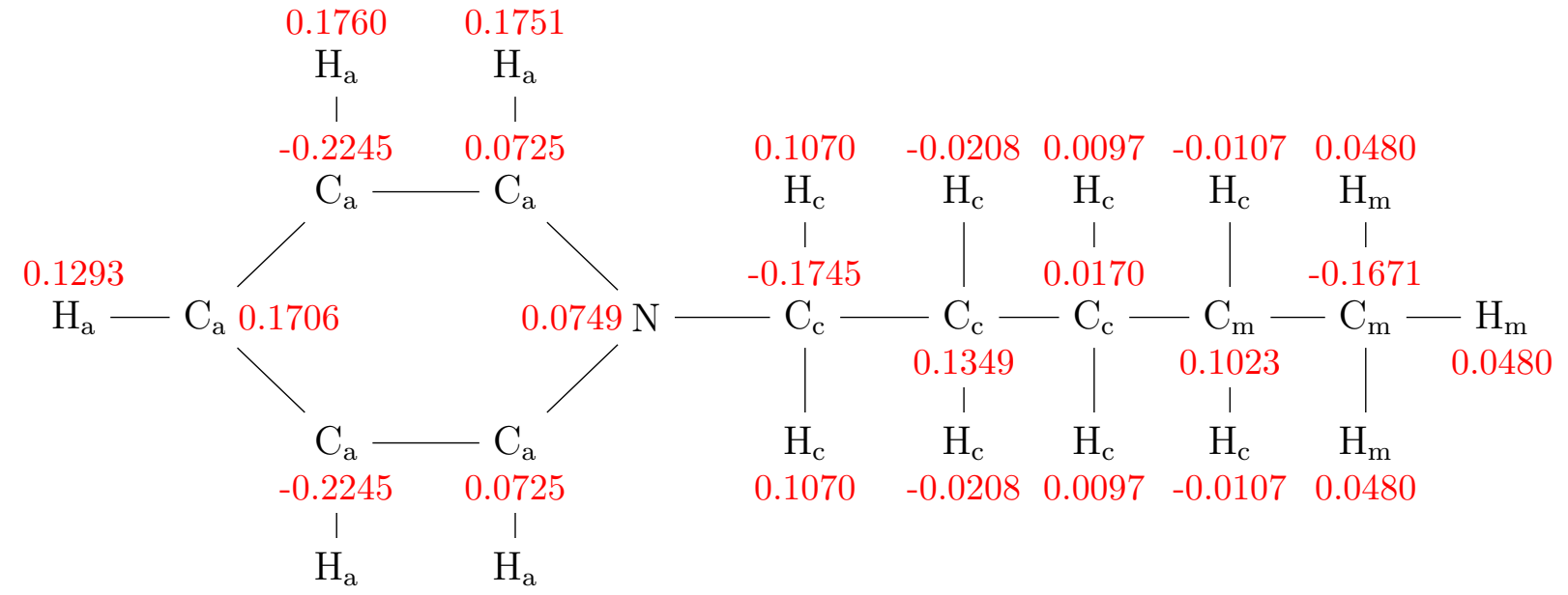

$0.1760 \quad 0.1751$

Figure S7: Structure of the $\left[\mathrm{C}_{5} \mathrm{Py}\right]^{+}$cation with atom types and corresponding point charges $q$ /e in red.

Table S11: Parameters $m_{n}, k_{m}^{\mathrm{dp}}$ and $\psi_{m}^{0}$ for the torsion potential $V_{\kappa \lambda \omega \tau}^{\mathrm{dp}}=\sum_{n} k_{m}^{\mathrm{dp}}[1+$ $\left.\cos \left(m_{n} \psi_{m}-\psi_{m}^{0}\right)\right]$ in the force field of the $\left[\mathrm{C}_{6} \mathrm{Py}\right]^{+}$cation.

\begin{tabular}{ccccc}
\hline & $n(\kappa \lambda \omega \tau)$ & $m_{n}$ & $k_{m}^{\mathrm{dp}} / \mathrm{kJ} \mathrm{mol}^{-1}$ & $\psi_{m}^{0} /{ }^{\circ}$ \\
\hline $\mathrm{X}-\mathrm{C}_{\mathrm{a}}-\mathrm{C}_{\mathrm{a}}-\mathrm{X}$ & 1 & 2 & 15.1780 & 180.0 \\
\hline $\mathrm{X}-\mathrm{C}_{\mathrm{a}}-\mathrm{N}-\mathrm{X}$ & 1 & 2 & 15.1780 & 180.0 \\
\hline $\mathrm{C}_{\mathrm{a}}-\mathrm{N}-\mathrm{C}_{\mathrm{c}}-\mathrm{C}_{\mathrm{c}}$ & 1 & 2 & -0.4571 & 0 \\
& 2 & 4 & -0.4824 & 0 \\
\hline $\mathrm{N}-\mathrm{C}_{\mathrm{c}}-\mathrm{C}_{\mathrm{c}}-\mathrm{C}_{\mathrm{c}}$ & 1 & 1 & -2.6581 & 0.0 \\
& 2 & 3 & 6.6966 & 0.0 \\
& 3 & 4 & 0.3447 & 0.0 \\
\hline $\mathrm{C}_{\mathrm{c}}-\mathrm{C}_{\mathrm{c}}-\mathrm{C}_{\mathrm{c}}-\mathrm{C}_{\mathrm{c}}$ & 1 & 1 & 0.5700 & 0.0 \\
& 2 & 2 & 0.2527 & 0.0 \\
& 3 & 3 & 5.5338 & 0.0 \\
& 4 & 4 & 0.6355 & 0.0 \\
& 5 & 5 & 0.3093 & 0.0 \\
\hline $\mathrm{C}_{\mathrm{c}}-\mathrm{C}_{\mathrm{c}}-\mathrm{C}_{\mathrm{c}}-\mathrm{C}_{\mathrm{m}}$ & 1 & 1 & 0.7379 & 0.0 \\
& 2 & 2 & 0.2352 & 0.0 \\
& 3 & 3 & 5.9593 & 0.0 \\
& 4 & 4 & 0.5423 & 0.0 \\
& 5 & 5 & 0.2850 & 0.0 \\
\hline $\mathrm{C}_{\mathrm{c}}-\mathrm{C}_{\mathrm{c}}-\mathrm{C}_{\mathrm{m}}-\mathrm{H}_{\mathrm{m}}$ & 1 & 3 & 1.8773 & 0.0 \\
\hline
\end{tabular}




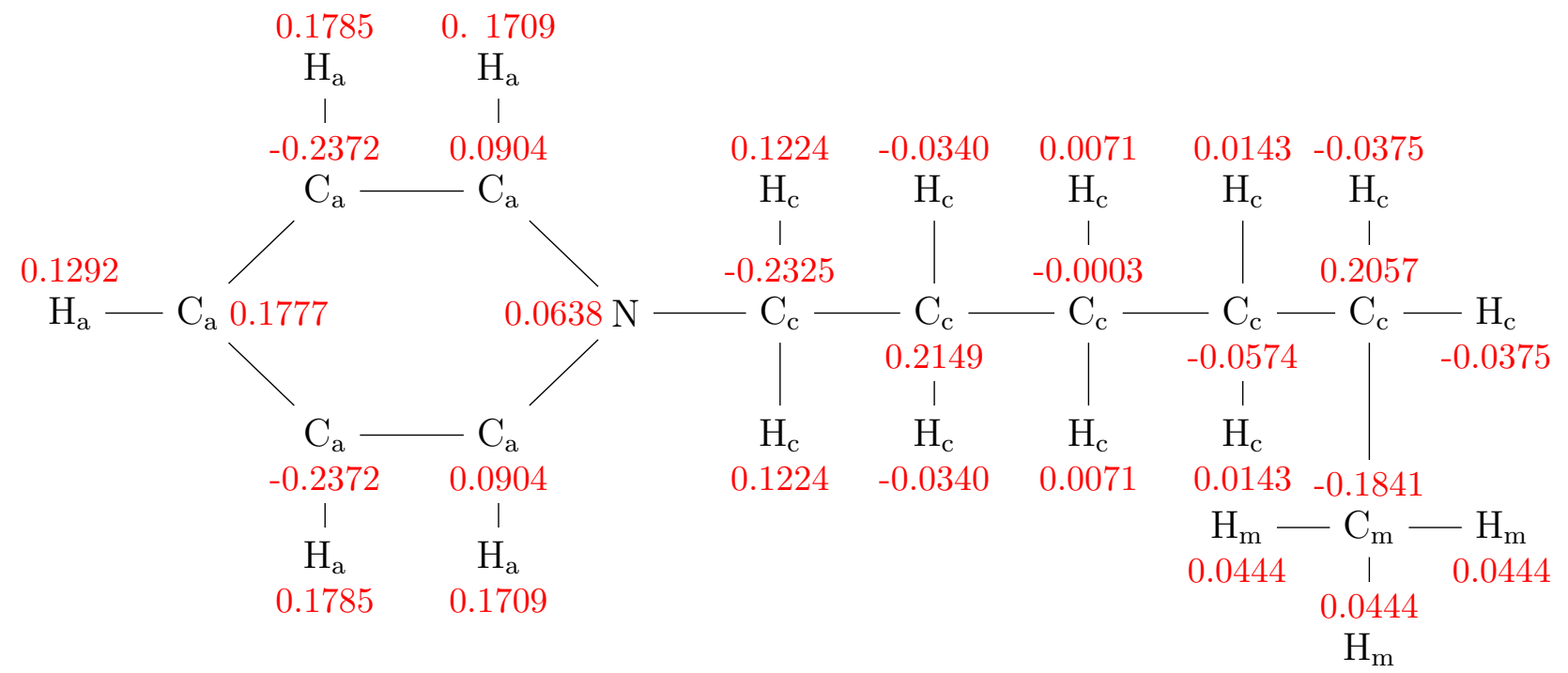

Figure S8: Structure of the $\left[\mathrm{C}_{6} \mathrm{Py}\right]^{+}$cation with atom types and corresponding point charges in red.

\section{Molecular Dynamics Simulation}

The $N p T$ molecular dynamics simulations on the $\left[\mathrm{HOC}_{n} \mathrm{Py}\right]\left[\mathrm{NTf}_{2}\right]$ ILs with $n=2-5$ were done using Gromacs 5.0.6 [7-11]. To build our simulation boxes of 512 ion pairs we arranged the ions on an interpenetrating primitiv cubic lattice and equilibrated the systems at $500 \mathrm{~K}$ for $2 \mathrm{~ns}$ employing the BERENDSEN thermostat and barostat [12] with coupling times of $\tau_{\mathrm{T}}=\tau_{\mathrm{p}}=0.5 \mathrm{ps}$. The systems were the equilibrated again for $2 \mathrm{~ns}$ at the desired temperature of $300 \mathrm{~K}$.

After the equilibration, production runs of 100 ns were carried out, employing the NoséHoover thermostat $[13,14]$ and the PARRInello-RAHMAn barostat $[15,16]$ with coupling times of $\tau_{\mathrm{T}}=1 \mathrm{ps}$ and $\tau_{\mathrm{p}}=2 \mathrm{ps}$ respectively. All simulations were done with a $2.0 \mathrm{fs}$ time step employing periodic boundary conditions and the LINCS algorithm [17] for fixed bond lengths. The smooth particle mesh EwALD summation [18] was applied in the liquid with a mesh spacing of $0.12 \mathrm{~nm}$, a real space cutoff of $0.9 \mathrm{~nm}$ and 4 th order interpolation. The relative accuracy of the EWALD sum was set to $10^{-5}$ corresponding to a convergence factor $\alpha=3.38 \mathrm{~nm}^{-1}$.

\section{Hydrogen Bond Criteria}

Whether a pair of ions is hydrogen-bonded or not is decided by geometric criteria, extracted from pair correlation functions and probability density plots (Figure S9 and S10). Figure S10 shows a maximum in the probability density function at short intermolecular $\mathrm{O}-\mathrm{H}$ distances and a linear HB angle $\alpha$ at $\cos (\alpha)=-1$ for the (cc) as well as the (ca) 


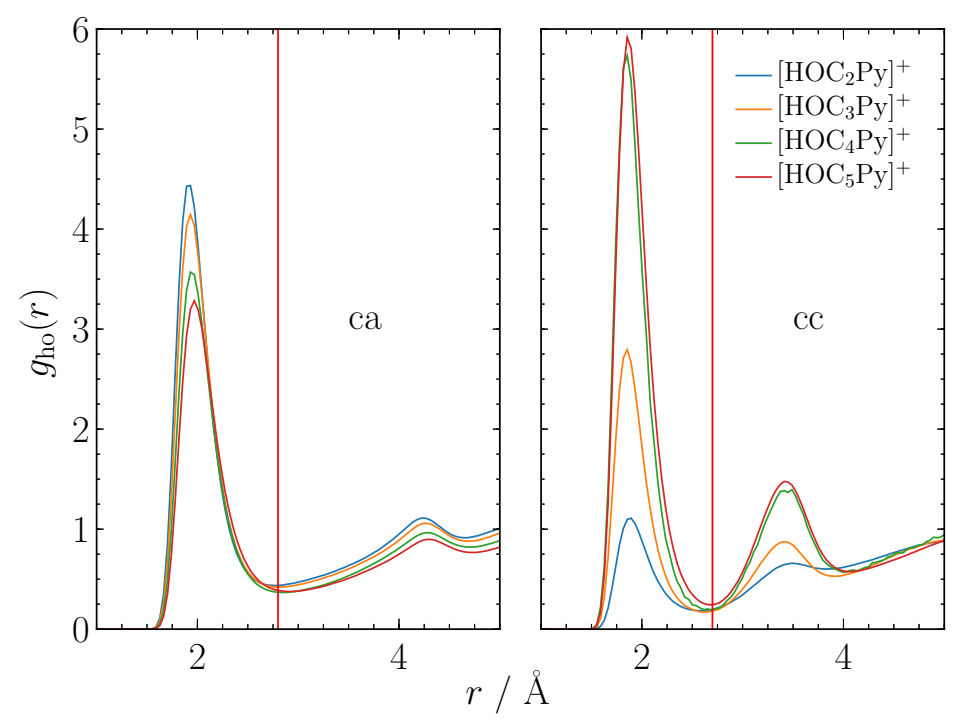

Figure S9: Pair correlation functions between the hydroxyl hydrogen of the cation and oxygen atoms on the anion (ca, left) and the cation (cc, right) for the different chain lengths obtained at $300 \mathrm{~K}$. The distance cutoff used to define the HB is shown as a red horizontal line at $2.8 \AA$ for the (ca) HB (left) and $2.7 \AA$ for the (cc) HB (right) respectively.

HB. As the intermolecular distance between hydrogen and oxygen increases the angle of the HB becomes more bent. To define the HB we chose an angle cutoff of $\cos (\alpha) \leq-0.5$ $\left(\alpha \geq 120^{\circ}\right)$ and a distance cutoff of $r_{\mathrm{c}}=2.7 \AA$ for the (cc) HB and $r_{\mathrm{c}}=2.8 \AA$ for the (ca) HB respectively.

Figure S11 shows the average percentage of cations per timestep involved in hydrogen bonding with anions and other cations respectively. Cations not forming a HB are considered "free" and mostly interact with the flourine atoms on the anion or are transitioning between different kinds of interactions. 

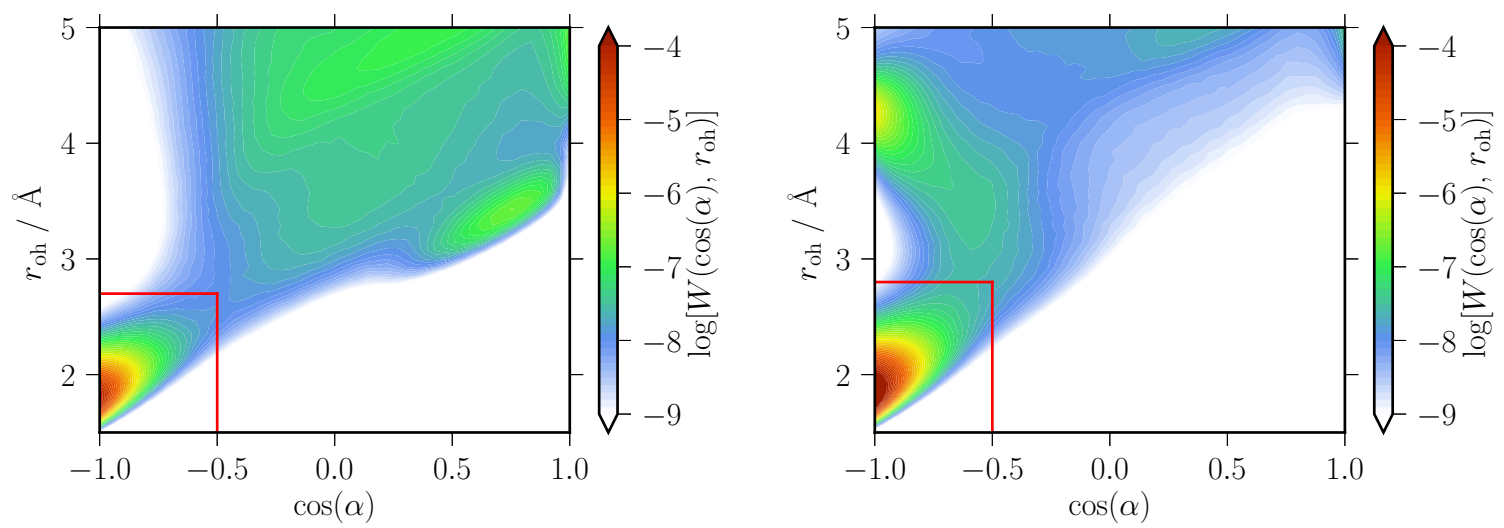

(a) $\left[\mathrm{HOC}_{2} \mathrm{Py}\right]\left[\mathrm{NTf}_{2}\right]$
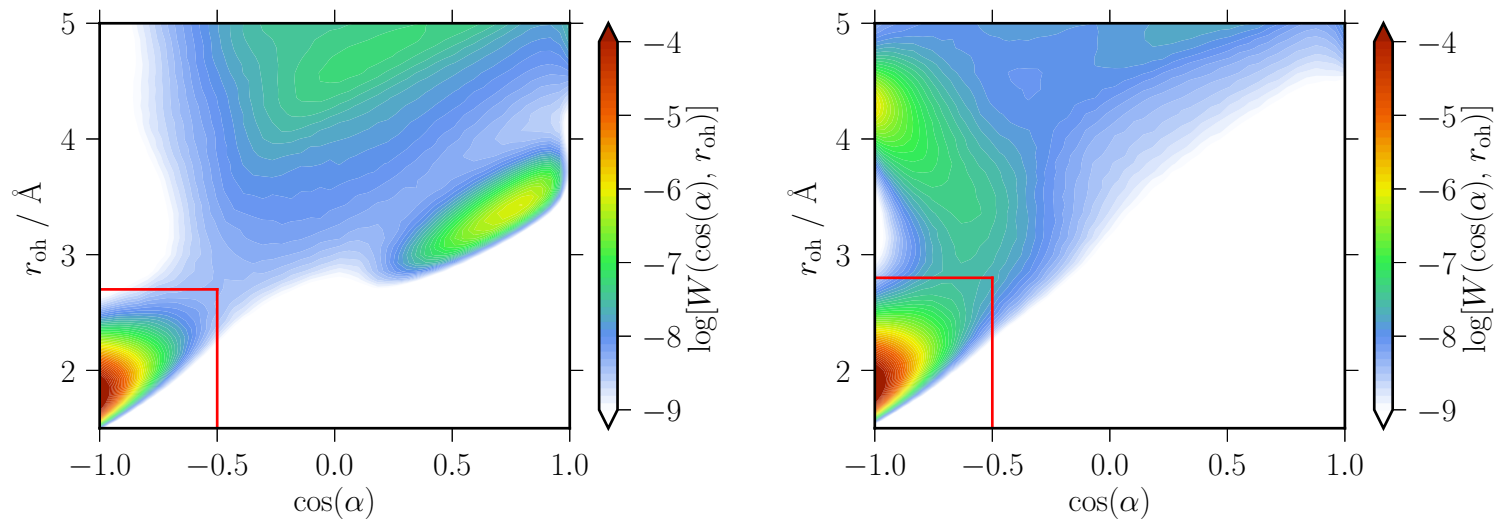

(b) $\left[\mathrm{HOC}_{3} \mathrm{Py}\right]\left[\mathrm{NTf}_{2}\right]$ 

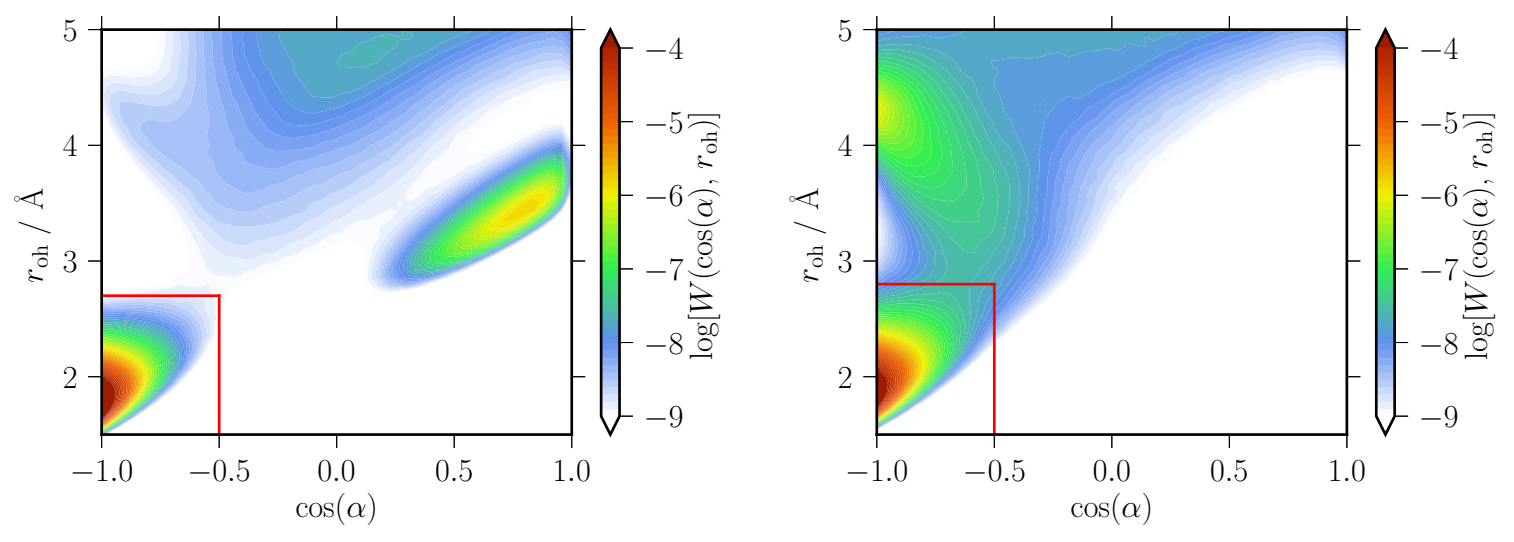

(c) $\left[\mathrm{HOC}_{4} \mathrm{Py}\right]\left[\mathrm{NTf}_{2}\right]$
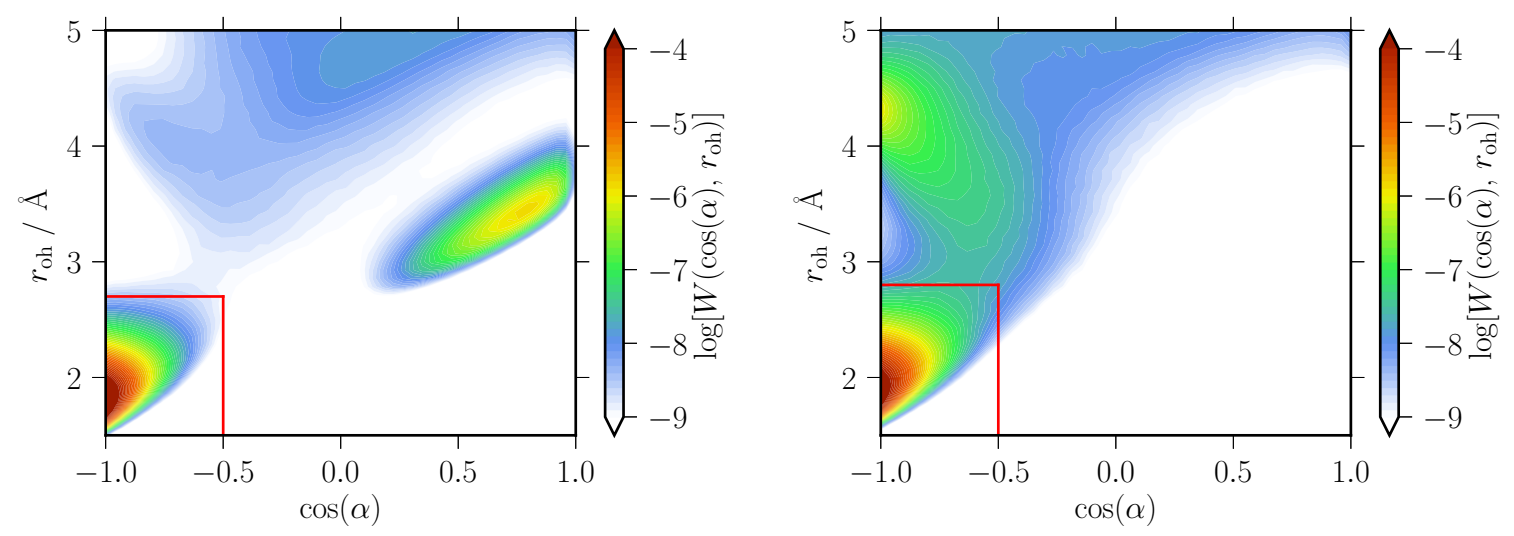

(d) $\left[\mathrm{HOC}_{5} \mathrm{Py}\right]\left[\mathrm{NTf}_{2}\right]$

Figure S10: Logarithmic representation of the probability density of finding an intermolecular $\mathrm{O}-\mathrm{H}$ distance $r_{\mathrm{oh}}$ and the cosine of the angle $\alpha$ between the intermolecular $\mathrm{H}-\mathrm{O}$ vector and the intramolecular $\mathrm{O}-\mathrm{H}$ vector for the (cc) (left) and the (ca) (right) HB obtained at $300 \mathrm{~K}$ for the specified ionic liquid. The probability density is weighted with $r^{-2}$. The (cc) HB for all considered ionic liquids can be characterised by a distance cutoff of $r_{\mathrm{c}}=2.7 \AA$ and an angular cutoff at $\cos \left(\alpha_{c}\right)=-0.5$. For the (ca) HB the same angular cutoff was used with a distance cutoff of $r_{\mathrm{c}}=2.8 \AA$. 


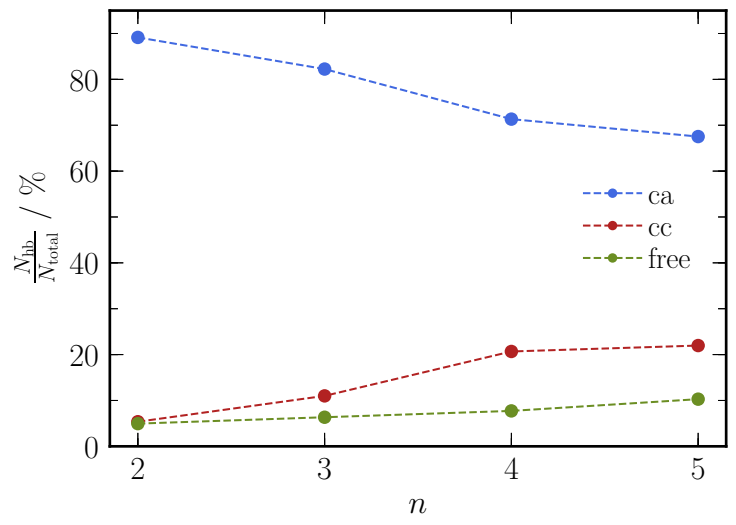

Figure S11: Percentage of cations donating a (ca) (blue) or (cc) (red) HB respectively. With increasing alkyl chain length the amount of (cc) hydrogen bonding increases, whereas the amount of (ca) hydrogen bonding decreases. Cations that do not form HB as defined in Figure S10 interact with different parts of the two ions and are considered "free" (green). 


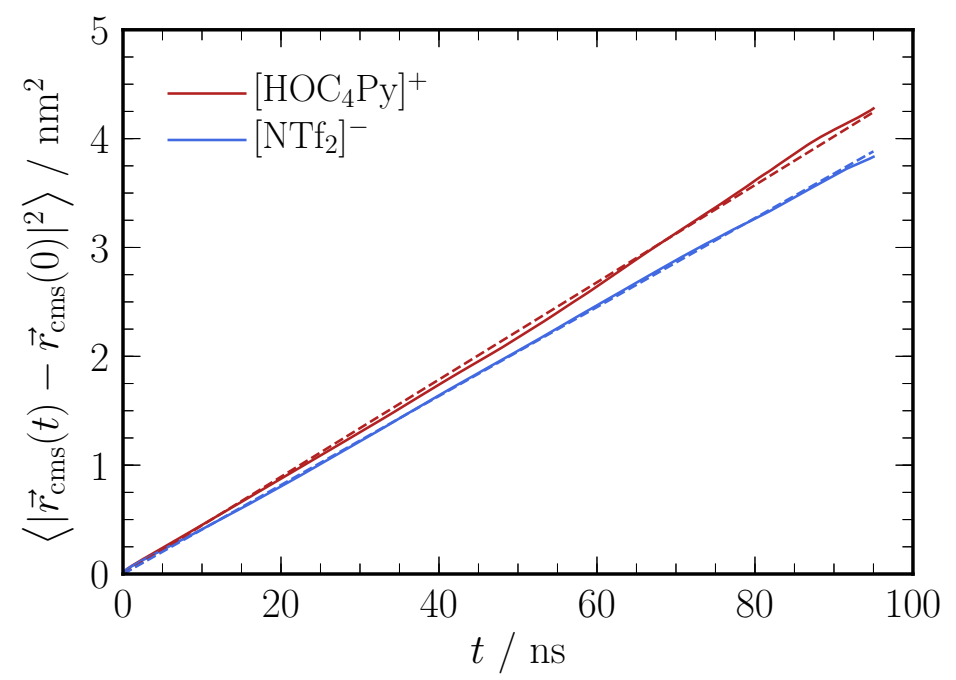

Figure S12: Mean square displacement of the cation (red) and anion (blue) in $\left[\mathrm{HOC}_{4} \mathrm{Py}\right]\left[\mathrm{NTf}_{2}\right]$ at $300 \mathrm{~K}$ (solid lines) and the corresponding fitted functions according to Eq. 2 (dashed lines).

\section{Mean Square Displacement and Diffusion}

To obtain the self-diffusion coefficients of the ions in our ionic liquid we used the Einstein relation

$$
D=\frac{1}{6} \frac{\partial}{\partial t} \lim _{t \rightarrow \infty}\left\langle\left|\vec{r}_{\mathrm{cms}}(t)-\vec{r}_{\mathrm{cms}}(0)\right|^{2}\right\rangle,
$$

where $\vec{r}_{\mathrm{cms}}$ denotes the position vector of the center of mass of the respective ion. The brackets indicate averaging over all $t=0$ and ions of the desired type. The mean square displacement $\left\langle\left|\vec{r}_{\mathrm{cms}}(t)-\vec{r}_{\mathrm{cms}}(0)\right|^{2}\right\rangle$ was fitted over a range from $10 \mathrm{~ns}$ to $95 \mathrm{~ns}$ to obtain the self-diffusion coefficient $D$ according to Eq. 2. The self-diffusion coefficients of the cations $D_{\text {Cation }}$ and anions $D_{\text {Anion }}$ in the functionalized and unfunctionalized IL for the different temperatures can be found in Table S12 and S13, respectively. The errors given in the tables represent two times the standard error of the mean $(2 \cdot s \bar{D})$ and were determined by calculating the diffusion coefficient for every ion separatly and then averaging over ions of the same kind.

\section{Hydrogen Bond Lifetime}

To calculate the HB lifetime $\tau_{\mathrm{hb}}$, we fitted the average HB population-correlation function to a sum of two streched exponential functions:

$$
C(t)=A_{1} \cdot \exp \left(-\left(\frac{t}{\tau_{1}}\right)^{\beta_{1}}\right)+A_{2} \cdot \exp \left(-\left(\frac{t}{\tau_{2}}\right)^{\beta_{2}}\right) .
$$


Table S12: Temperature dependence of the self-diffusion coefficient of the cation $D_{\text {Cation }}$ and the anion $D_{\text {Anion }}$ in the respective functionalized ionic liquid.

\begin{tabular}{|c|c|c|}
\hline$T / \mathrm{K}$ & $D_{\text {Cation }} / 10^{-11} \mathrm{~m}^{2} \mathrm{~s}^{-1}$ & $D_{\text {Anion }} / 10^{-11} \mathrm{~m}^{2} \mathrm{~s}^{-1}$ \\
\hline & {$\left[\mathrm{HOC}_{2} \mathrm{Py}\right]\left[\mathrm{NTf}_{2}\right]$} & \\
\hline 300 & $1.32 \pm 0.08$ & $1.01 \pm 0.06$ \\
\hline 320 & $3.33 \pm 0.20$ & $2.70 \pm 0.17$ \\
\hline 340 & $6.5 \pm 0.5$ & $5.5 \pm 0.4$ \\
\hline 360 & $11.0 \pm 0.7$ & $9.0 \pm 0.6$ \\
\hline 380 & $17.3 \pm 1.1$ & $13.9 \pm 0.0$ \\
\hline \multirow[t]{2}{*}{400} & $23.8 \pm 1.4$ & $20.3 \pm 1.2$ \\
\hline & {$\left[\mathrm{HOC}_{3} \mathrm{Py}\right]\left[\mathrm{NTf}_{2}\right]$} & \\
\hline 300 & $1.14 \pm 0.07$ & $0.95 \pm 0.06$ \\
\hline 320 & $2.85 \pm 0.17$ & $2.25 \pm 0.14$ \\
\hline 340 & $5.7 \pm 0.4$ & $4.7 \pm 0.3$ \\
\hline 360 & $9.3 \pm 0.7$ & $8.2 \pm 0.6$ \\
\hline 380 & $15.7 \pm 1.0$ & $13.3 \pm 0.9$ \\
\hline \multirow[t]{2}{*}{400} & $23.1 \pm 1.3$ & $18.2 \pm 1.2$ \\
\hline & {$\left[\mathrm{HOC}_{4} \mathrm{Py}\right]\left[\mathrm{NTf}_{2}\right]$} & \\
\hline 300 & $0.74 \pm 0.05$ & $0.68 \pm 0.05$ \\
\hline 320 & $1.81 \pm 0.11$ & $1.66 \pm 0.10$ \\
\hline 340 & $4.21 \pm 0.26$ & $3.76 \pm 0.22$ \\
\hline 360 & $7.4 \pm 0.5$ & $6.7 \pm 0.4$ \\
\hline 380 & $12.4 \pm 0.7$ & $11.0 \pm 0.6$ \\
\hline \multirow[t]{2}{*}{400} & $19.5 \pm 1.3$ & $17.1 \pm 1.0$ \\
\hline & {$\left[\mathrm{HOC}_{5} \mathrm{Py}\right]\left[\mathrm{NTf}_{2}\right]$} & \\
\hline 300 & $0.63 \pm 0.04$ & $0.60 \pm 0.04$ \\
\hline 320 & $1.70 \pm 0.11$ & $1.60 \pm 0.10$ \\
\hline 340 & $3.71 \pm 0.22$ & $3.16 \pm 0.18$ \\
\hline 360 & $6.6 \pm 0.4$ & $6.5 \pm 0.5$ \\
\hline 380 & $11.7 \pm 0.7$ & $10.2 \pm 0.7$ \\
\hline 400 & $17.8 \pm 1.1$ & $17.7 \pm 1.1$ \\
\hline
\end{tabular}


Table S13: Temperature dependence of the self-diffusion coefficient of the cation $D_{\text {Cation }}$ and the anion $D_{\text {Anion }}$ in the respective unfunctionalized ionic liquid.

\begin{tabular}{|c|c|c|}
\hline$T / \mathrm{K}$ & $D_{\text {Cation }} / 10^{-11} \mathrm{~m}^{2} \mathrm{~s}^{-1}$ & $D_{\text {Anion }} / 10^{-11} \mathrm{~m}^{2} \mathrm{~s}^{-1}$ \\
\hline \multicolumn{3}{|c|}{$\left[\mathrm{C}_{3} \mathrm{Py}\right]\left[\mathrm{NTf}_{2}\right]$} \\
\hline 300 & $3.54 \pm 0.21$ & $2.25 \pm 0.14$ \\
\hline 320 & $6.7 \pm 0.4$ & $4.36 \pm 0.26$ \\
\hline 340 & $10.5 \pm 0.7$ & $7.6 \pm 0.5$ \\
\hline 360 & $17.7 \pm 1.2$ & $11.8 \pm 0.7$ \\
\hline 380 & $24.8 \pm 1.4$ & $17.9 \pm 1.1$ \\
\hline 400 & $33.4 \pm 2.0$ & $25.6 \pm 1.7$ \\
\hline \multicolumn{3}{|c|}{$\left[\mathrm{C}_{4} \mathrm{Py}\right]\left[\mathrm{NTf}_{2}\right]$} \\
\hline 300 & $2.51 \pm 0.15$ & $1.85 \pm 0.12$ \\
\hline 320 & $5.4 \pm 0.4$ & $3.81 \pm 0.25$ \\
\hline 340 & $9.1 \pm 0.6$ & $6.6 \pm 0.4$ \\
\hline 360 & $14.9 \pm 0.9$ & $11.5 \pm 0.7$ \\
\hline 380 & $21.8 \pm 1.3$ & $17.0 \pm 1.0$ \\
\hline 400 & $30.9 \pm 1.9$ & $24.5 \pm 1.6$ \\
\hline \multicolumn{3}{|c|}{$\left[\mathrm{C}_{5} \mathrm{Py}\right]\left[\mathrm{NTf}_{2}\right]$} \\
\hline 300 & $0.82 \pm 0.06$ & $0.67 \pm 0.04$ \\
\hline 320 & $3.98 \pm 0.24$ & $3.17 \pm 0.21$ \\
\hline 340 & $7.7 \pm 0.5$ & $6.1 \pm 0.4$ \\
\hline 360 & $12.2 \pm 0.8$ & $10.0 \pm 0.7$ \\
\hline 380 & $18.4 \pm 1.2$ & $16.0 \pm 1.0$ \\
\hline 400 & $26.1 \pm 1.5$ & $19.5 \pm 1.2$ \\
\hline \multicolumn{3}{|c|}{$\left[\mathrm{C}_{6} \mathrm{Py}\right]\left[\mathrm{NTf}_{2}\right]$} \\
\hline 300 & $1.30 \pm 0.08$ & $1.12 \pm 0.07$ \\
\hline 320 & $3.15 \pm 0.19$ & $2.67 \pm 0.17$ \\
\hline 340 & $5.9 \pm 0.4$ & $5.1 \pm 0.4$ \\
\hline 360 & $9.6 \pm 0.6$ & $8.6 \pm 0.5$ \\
\hline 380 & $16.2 \pm 1.0$ & $13.6 \pm 0.8$ \\
\hline 400 & $21.3 \pm 1.3$ & $21.0 \pm 136$ \\
\hline
\end{tabular}


Table S14: HB lifetime of the (ca) HB $\tau_{\text {ca }}$ and of the (cc) HB $\tau_{\mathrm{cc}}$ as a function of the alkyl chain length $n$ in $\left[\mathrm{HOC}_{n} \mathrm{Py}\right]\left[\mathrm{NTf}_{2}\right]$ at $300 \mathrm{~K}$.

\begin{tabular}{rrr}
\hline$n$ & $\tau_{\text {ca }} / \mathrm{ps}$ & $\tau_{\text {cc }} / \mathrm{ps}$ \\
\hline 2 & $561 \pm 27$ & $220 \pm 9$ \\
3 & $614 \pm 25$ & $442 \pm 15$ \\
4 & $800 \pm 40$ & $1110 \pm 50$ \\
5 & $870 \pm 50$ & $1120 \pm 50$ \\
\hline
\end{tabular}

To get a consistent fitting behavior the parameter $A_{2}$ was fixed for all ILs at 0.048 for the (ca) correlation functions and 0.25 for the (cc) correlation functions. Eq. 3 can be integrated analytically to obtain the HB lifetime $\tau_{\mathrm{hb}}$ (Table S14) using

$$
\tau_{\mathrm{hb}}=A_{1} \cdot \frac{\tau_{1}}{\beta_{1}} \Gamma\left(\beta_{1}^{-1}\right)+A_{2} \cdot \frac{\tau_{2}}{\beta_{2}} \Gamma\left(\beta_{2}^{-1}\right) .
$$

To obtain the error bars of the HB lifetimes, we calculated the corresponding HB population-correlation function for every hydroxyl group separatly and integrated them numerically using Simpson's rule. The error given in Table S14 corresponds to $2.5 \cdot s_{\bar{\tau}_{\mathrm{hb}}}$ where $s_{\bar{\tau}_{\mathrm{hb}}}$ denotes the standard error of the mean of the obtained HB lifetimes. 


\section{References}

[1] J. Neumann, B. Golub, L.-M. Odebrecht, R. Ludwig, D. Paschek, J. Chem. Phys. 2018, 148, 193828.

[2] W. L. Jorgensen, D. S. Maxwell, J. Tirado-Rives, J. Am. Chem. Soc. 1996, 118, $11225-11236$.

[3] W. L. Jorgensen, N. A. McDonald, J. Mol. Struct.: THEOCHEM 1998, 424, 145155.

[4] C. M. Breneman, K. B. Wiberg, J. Comput. Chem. 1990, 11, 361-373.

[5] M. Frisch, G. Trucks, H. Schlegel, G. Scuseria, M. Robb, J. Cheeseman, G Scalmani, V Barone, B Mennucci, G. Petersson, et al., Wallingford CT 2013.

[6] D. Paschek, A. Geiger, Department of Physical Chemistry University of Dortmund 2002.

[7] S. Páll, M. J. Abraham, C. Kutzner, B. Hess, E. Lindahl in International Conference on Exascale Applications and Software, Springer, 2014, pp. 3-27.

[8] S. Pronk, S. Páll, R. Schulz, P. Larsson, P. Bjelkmar, R. Apostolov, M. R. Shirts, J. C. Smith, P. M. Kasson, D. van der Spoel, et al., Bioinformatics 2013, 29, $845-854$.

[9] B. Hess, C. Kutzner, D. Van Der Spoel, E. Lindahl, J. Chem. Theory Comput. 2008, 4, 435-447.

[10] D. Van Der Spoel, E. Lindahl, B. Hess, G. Groenhof, A. E. Mark, H. J. Berendsen, J. Comput. Chem. 2005, 26, 1701-1718.

[11] H. J. Berendsen, D. van der Spoel, R. van Drunen, Comput. Phys. Commun. 1995, 91, 43-56.

[12] H. J. C. Berendsen, J. P. M. Postma, W. F. van Gunsteren, A. DiNola, J. R. Haak, J. Chem. Phys. 1984, 81, 3684-3690.

[13] S. Nosé, Mol. Phys. 1984, 52, 255-268.

[14] W. G. Hoover, Phys. Rev. A 1985, 31, 1695-1697.

[15] M. Parrinello, A. Rahman, J. Appl. Phys. 1981, 52, 7182-7180.

[16] S. Nosé, M. L. Klein, Mol. Phys. 1983, 50, 1055-1076.

[17] B. Hess, H. Bekker, H. J. C. Berendsen, J. G. E. M. Fraaije, J. Comp. Chem. 1997, 18, 1463-1472.

[18] U. Essmann, L. Perera, M. L. Berkowitz, T. A. Darden, H. Lee, L. G. Pedersen, J. Chem. Phys. 1995, 103, 8577-8593. 